HANNA KONOPKA (Białystok)

\title{
NAUCZANIE RELIGII W SZKOŁACH POLSKI LUDOWEJ (1944-1950)
}

Status religii, jako przedmiotu nauczania, był od wieków mocno ugruntowany w szkolnictwie polskim. Był on odbiciem wysokiej rangi Kościoła katolickiego w państwie i społeczeństwie polskim. Przemiany ustrojowe, zapoczątkowane w szkolnictwie polskim po zakończeniu II wojny światowej, zmierzały między innymi w kierunku laicyzacji i przepojenia go ateistyczną ideologia komunistyczną. W pierwszych powojennych latach Kościół, duchowieństwo oraz nauczyciele religii znaleźli się w swej ogromnej większości w obozie, który „władza ludowa” darzyła nie skrywaną wrogością. Postępowanie komunistów w stosunku do katechizacji szkolnej odbierane było w świadomości społecznej przede wszystkim jako ich stosunek do religii, do wiary ${ }^{1}$.

Problematyka stosunków między władzami partyjno-państwowymi, w tym oświatowymi, a hierarchią, duchowieństwem i wierzącym społeczeństwem, w związku z nauczaniem religii w szkołach, to splot zagadnień:

przede wszystkim podstaw prawnych obecności religii w szkolnictwie, ich przestrzegania i urzędowej interpretacji,

- statusu prawnego nauczycieli religii, ich angażowania, kwalifikacji i zwalniania,

1 Ramy niniejszego artykułu pozwalają jedynie na zasygnalizowanie ważniejszych zagadnien. Szerzej: H. Konopka, Religia w szkotach Polski Ludowej. Problem nauczania religii $w$ polityce państwa (1944-1961), wyd. II, Białystok 1998; 17 lat nauczania religii w Polsce Ludowej. Wybór dokumentów, opr.: H. Konopka, Białystok 1998. Także: J. Żaryn, Kościót a władza w Polsce (1945-1950), Warszawa 1997; S. Wójcik, Katechizacja w warunkach systemu totalitarnego. Na przykładzie Administracji Apostolskiej Dolnego Ślaska w latach 1945-1961, Wrocław 1995. 
- możliwości i zakresu katechizacji zgodnie z misją Kościoła

- oraz wykonywania praktyk religijnych na terenie szkoły.

Pomimo konfrontacji między komunistycznymi władzami państwa a Kościołem w ciągu pierwszych siedemnastu lat istnienia Polski Ludowej religia pozostawała jednak przedmiotem nauczania szkolnego. Co prawda jej status ulegał zmianie, jednak ciagle pozostawała ona w planach lekcyjnych, przynajmniej w części szkół. Był to ewenement w skali „krajów demokracji ludowej".

"Władza ludowa" od początku swego istnienia dążyła do wprowadzenia i egzekwowania swoiście rozumianej zasady rozdziału Kościoła od państwa. Jednak do 22 lipca 1952 r., to jest do uchwalenia Konstytucji PRL, formalnie obowiązywały podstawowe założenia Konstytucji marcowej 1921 r. Szkolnictwo funkcjonowało w zasadzie na podstawie przedwojennego ustawodawstwa oświatowego. W nowej rzeczywistości politycznej władze oświatowe tendency jnie interpretowały jednak te regulacje. Stanowiło to zarzewie konfliktów: kwestia nauczania religii stała się fragmentem walki politycznej i ideologicznej na gruncie systemu oświatowego.

Powojenna przebudowa oświaty polskiej miała na celu zmianę ustroju szkolnego: jego podstaw organizacyjnych, ale przede wszystkim dotychczasowej ideologii wychowawczej ${ }^{2}$. Chodziło o zmianę istoty wychowania młodzieży polskiej: z państwowego i narodowego - religijnego, na socjalistyczne - świeckie. Walka o to była płaszczyzną ciągłych napięć w polskiej oświacie. Początkowo otwieraniu nowych szkół i wznawianiu w nich zajęć lekcyjnych towarzyszyły tradycy jne obrzędy religijne oraz podejmowanie nauki religii. Próby przeciwdziałania tym praktykom, zabiegi mające na celu ograniczenie obecności Kościoła na terenie szkoły, spotykały się z powszechną i ostrą reakcją klerw, nauczycieli, rodziców i dzieci.

W Tymczasowym Rządzie Jedności Narodowej stanowisko ministra oświaty powierzono Czesławowi Wycechowi (28 czerwca 1945 r.). Sprawiać mogło to wrażenie, że rząd, utworzony na szerszej bazie społecznej i politycznej, w projektowanej reformie szkolnictwa odstąpić może od najbardziej drastycznych zmian - m.in. w zakresie ograniczania nauczania religii i praktyk religijnych w szkołach. Proponowana przez władze oświatowe fakultatywność nauki religii została ostro zaatakowana w prasie katolickiej. Ks. Jan Piwowarczyk pisał: „Odrzucając przymus Kościół stoi jednak na stanowisku

2 Szerzej m. in.: S. Mauersberg, Reforma szkolnictwa w Polsce 1944-1948, Wrocław 1974; B. Potyrała, Przemiany oświaty w Polsce w latach 1944-1948, Wrocław 1991. 
obowiązkowości nauki religii i praktyk religijnych w szkole dla dzieci zapisanych jako katolickie" ${ }^{3}$. Nadzieje części działaczy oświatowych, wiązane z osobą Wycecha, nie spełniły się jednak. W wywiadzie udzielonym kilka dni po objęciu stanowiska Wycech potwierdził respektowanie przez ministerstwo zasady wolności sumienia i wyznania, a w stosunku do osób, które „...nie mogą się zmieścić w ramach określonych związków wyznaniowych, nie będzie stosowany przymus praktyk religijnych" ${ }^{4}$.

Zagadnienie nauczania religii w szkołach, a raczej jej ograniczania, wymagało rozwiązania co najmniej dwóch problemów prawnych: ustaleń wynikających z Konkordatu oraz postanowień Konstytucji marcowej. Uchwała Tymczasowego Rządu Jedności Narodowej z 12 września 1945 r. o wygaśnięciu Konkordatu rozwiązywała formalnie problem pierwszy ${ }^{5}$.

Druga kwestia wymagała znalezienia odpowiedzi na pytania:

- czy w świetle postanowień Konstytucji marcowej nauka religii w szkołach jest obowiązkowa dla wszystkich uczniów mających mniej niż 18 lat

- oraz jak ma być udzielana nauka religii uczniom, których rodzice (opiekunowie) należą do związku religijnego dotychczas prawnie nieuznawanego?

Odpowiedzi na te pytania zawierał Okólnik Ministra Oświaty $z$ dn. 13 września 1945 r. ${ }^{6}$ Istota okólnika sprowadzała się do stwierdzeń, że nauka religii jest obowiązkowa dla uczniów przynależnych do wyznań uznanych przez Państwo, natomiast uczniowie, których rodzice (prawni opiekunowie) zadeklarują, iż nie życzą sobie, by dzieci ich pobierały naukę religii, ponieważ nie odpowiada to ich przekonaniom religijnym, są od nauki tego przedmiotu zwolnieni. Okólnik wprowadzał więc nowy stan prawny. Z uczenia się religii, formalnie nadal będącej przedmiotem obowiązkowym, można było zrezygnować poprzez złożony przez rodziców (opiekunów) sprzeciw.

3 J. Piwowarczyk, Projekt reformy a wychowanie, „Tygodnik Powszechny” nr 12, 10 czerwca 1945.

4 „Życie Warszawy” nr 186, 13 lipca 1945 r.

5 Rada Ministrów powołała się na opinię Komisji Prawniczej przy Ministerstwie Sprawiedliwości, przygotowaną w sierpniu 1945 r. Por.: Dwie opinie prawne z dziedziny stosunków Kóścioła i państwa, "Demokratyczny Przegląd Prawniczy” 1945, nr 1. Sprawa Konkordatu - jego „wypowiedzenia”, „jednostronnego uchylenia”, czy też „wygaśnięcia”, leżąca poza zasadniczym tematem rozprawy, rzutowała jednak na rozpatrywanie kwestii szkolnego nauczania religii.

6 Okólnik nr 50 z 13 września 1945 r. w sprawie nauki szkolnej religii, Dz. Urz. MOśw. 1945, nr 4, poz. 189. 
Sprawa świeckiego charakteru szkoły pojawiła się na marginesie obrad II Konferencji Nauczycieli Członków PPR (7-8 października 1945 r.), Ogólnopolskiego Zjazdu Nauczycieli Członków PPS (16-17 listopada 1945 r.) oraz na konferencji aktywu nauczycielskiego PPS i PPR (23-24 marca 1946 r. $)^{7}$. Uczestnicy konferencji wzywali m.in. do popularyzowania w szkołach okólnika w sprawie zwalniania dzieci od przymusu pobierania nauki religii oraz zwracali uwagę nauczycieli, że nie są oni zobowiązani do nadzorowania udziału dzieci w praktykach religijnych.

Działalność Kościoła w nowych warunkach stała się przedmiotem obrad pierwszej po zakończeniu wojny Konferencji Plenarnej Episkopatu (3-4 października 1945 r. $)^{8}$. Biskupi zwrócili się do katolików polskich $\mathrm{z}$ apelem o zapewnienie młodzieży nauki religii w szkołach i wychowanie w duchu chrześcijańskim ${ }^{9}$. Konferencja Plenarna powołała Komisję Szkolną Episkopatu ${ }^{10}$.

Egzekwowanie wykonania Okólnika z 13 września 1945 r. nie sprawiało kłopotu. W pierwszej kolejności zwrócono uwagę na licea pedagogiczne ${ }^{11}$. W programie nauczania w liceach pedagogicznych w roku szkolnym 1946/47, pozostawiono 1 godzinę lekcy jną na naukę religii ${ }^{12}$. W szkołach zawodowych i dla dorosłych, w roku szkolnym 1946/47, zmniejszono liczbę godzin nauki religii z 2 do 1 godziny tygodniowo ${ }^{13}$.

7 S. Mauersberg, op. cit., s. 107 i n. Kongresy te obradowały w Warszawie.

8 Biskupi obradowali pod przewodnictwem prymasa kard. Augusta Hlonda, który wrócił do kraju w lipcu 1945 r. Po powrocie do kraju prymas Hlond przebywał w Poznaniu, nie śpiesząc się z nawiązaniem kontaktów z władzami państwowymi w Warszawie. Prymas opuścił Poznań i przeniósł się do Warszawy 29 kwietnia 1946 r. Szerzej: M. Piotrowski, Stużba idei czy serwilizm? Zygmunt Felczak i Feliks Widy-Wirski w najnowszych dziejach Polski, Lublin 1994, s. 245 i n.

9 Listy pasterskie Episkopatu Polski. 1945-1974, Paryż 1975, s. 23-24. Także: J. Wolny, Ostatnie lata działalności kościelnej Adama Stefana Sapiehy, w: Księga Sapieżyńska, pr. zb. pod red. ks. Jerzego Wolnego, t. II, Kraków 1986, s. 520 i n.

10 W skład komisji weszli: abp Adam Stefan Sapieha, biskupi: Włodzimierz Jasiński, Stanisław Rospond, Juliusz Bieniek oraz prałat Andrzej Wronka. Por. m.in.: M. Jakubiec, Abp Adam Stefan Sapieha jako przewodniczacy Komisji Szkolnej Episkopatu Polski, w: K'sięga Sapieżyńska..., s. 71-85. Także: W. Pomykało, Kościót milczenia?, Warszawa 1967, s. 43.

$11 \mathrm{Na}$ mocy zarządzenia Ministra Oświaty z 12 czerwca 1945 r. (Dz. Urz. MOśw, 1945, nr 2, poz. 57) w liceach pedagogicznych religia przestała być przedmiotem egzaminacyjnym podczas matury, a nauczycieli religii wyłączono z komisji egzaminacyjnych.

12 Okólnik nr 10 z dn. 11 lutego 1946 r., Dz. Urz. MOśw. 1946, nr 2 poz. 50. Religię pominięto natomiast w programie 4-tygodniowego kursu wakacyjnego, przygotowującego nauczycieli niekwalifikowanych.

13 Archiwum Akt Nowych Ministerstwo Oświaty (AAN MOśw.), sygn. 412, Zarządzenie z dn. 20 maja 1946 r. nr III. 1191/46 w sprawie organizacji roku szkolnego 1946/47 w szkołach zawodowych. 
Nawarstwianie się spraw związanych $\mathrm{z}$ nauczaniem religii, wychowaniem religijnym itp. spowodowało, że Episkopat Polski podjął te problemy na kolejnej Konferencji Plenarnej w dn. 22-24 maja 1946 r. W jej trakcie ustalono zasady postępowania duchowieństwa wobec władz ${ }^{14}$. Biskupi wyrazili troskę o religijne wykształcenie i wychowanie młodzieży, uznali, że „młodzież w obecnych stosunkach jest wystawiona więcej niż kiedykolwiek przedtem na moralne niebezpieczeństwa, Kościół musi ją otoczyć głęboką ojcowską opieką, aby nie wypaczyło się jej młode życie" ${ }^{15}$.

Reforma oświatowa, zapoczątkowana przez działaczy PPR, w okresie od lipca 1945 r. do stycznia 1947 r. nie była jednak realizowana konsekwentnie. Oddanie resortu oświaty w ręce Wycecha było kompromisem między zwolennikami i przeciwnikami kierunku reformowania oświaty. Wycech nie realizował $w$ pełni ideałów wychowawczych postulowanych przez PPR, ale też nie występował otwarcie przeciwko nim. Postępowanie takie było dość trudne, ponieważ Departament Reformy Szkolnej, na czele którego stała Żanna Kormanowa, znajdował się pod wpływem PPR. W kształtowaniu i realizacji polityki oświatowej działacze PPR ważne miejsce przewidywali dla nauczycieli. Uważając, że nauczyciel nie może być apolityczny, postawili sobie za cel przebudowanie jego światopoglądu. Komuniści i ich sojusznicy przeciwni byli kierunkowi działań reformatorskich realizowanych przez PSL-owską ekipę ministra Wycecha. Oceniali, że w resorcie nasiliły się tendencje reakcyjne, a zamiarem ludowców było odejście od reformy i przełożenie jej na „nieoznaczony ter$\min " 16$.

Po uchwaleniu małej Konstytucji 19 lutego 1947 r. władze oświatowe za miarodajną wykładnię kwestii nauczania religii przyjęły Uwagi o nie-

14 „Poszczególni biskupi mogą rozmawiać z władzami jedynie w sprawach dotyczących ich diecezji, natomiast generalne zagadnienia związane $\mathrm{z}$ problematyką stosunków państwa z Kościołem leżą w kompetencji konferencji plenarnej episkopatu oraz Komisji Głównej. Stanowiło to zabezpieczenie przed próbami różnicowania stanowiska poszczególnych hierarchów w sprawie sposobu uregulowania sytuacji Kościoła. (...) Unikać należy postawy, która by mogła być interpretrowana jako aprobata polityki rządowej lub jako kolaboracja z nim". Protokół Plenarnej Konferencji Episkopatu z 22-24 maja 1946 r., w: W. Kozub-Ciembroniewicz, J. Majchrowski, Najnowsza historia polityczna Polski. Wybór źródet, cz. IV, 1945-1948, Kraków 1993, s. 108. Por.: A. Dudek, Państwo i Kościót $w$ Polsce 1945-1970, Kraków 1995, s. 9.

15 Listy Pasterskie Episkopatu..., s. 39.

16 B. Jakubowska, Przeobrazenia w szkolnej edukacji historycznej w Polsce w latach 1944-1956, Warszawa 1986, s. 134 i n. 
których zagadnieniach ustaw konstytucyjnych z 4 i 19 lutego 1947 roku17. Mała Konstytucja nie tylko nie znosiła Konstytucji marcowej, ani Manifestu Lipcowego PKWN, ale wręcz na wstępie stwierdzała, że Konstytucję tę nadaje się w oparciu o podstawowe założenia tych aktów. Przyjęto, że z chwilą uchwalenia małej Konstytucji moc prawną zachowywały tylko te zapisy Konstytucji marcowej, które zostały w niej wyraźnie przytoczone. Ponieważ żaden $z$ artykułów Konstytucji marcowej dotyczących szkolnictwa i nauczania nie został w nowej Konstytucji powołany, uznano więc, że w tym zakresie ustawodawca nie podlega żadnym poprzednim ograniczeniom konstytucyjnym ${ }^{18}$.

Po zwycięstwie wyborczym Bloku Stronnictw Demokratycznych w styczniu 1947 r. utrzymywanie pozorów współpracy z lewicowym odłamem PSL (na dotychczasowych zasadach) okazało się dla komunistów zbędne. Ministrem oświaty został ponownie Stanisław Skrzeszewski. Zapoczątkowano wówczas wymianę kuratorów i inspektorów szkolnych związanych dotąd z PSL. W latach 1947-1948 nastąpił także gwałtowny wzrost liczby członków PPR, a następnie PZPR wśród nauczycieli ${ }^{19}$.

Nowa, PPR-owska ekipa zapowiadała zmianę sytuacji w szkolnictwie, kontynuację przebudowy treści edukacji szkolnej i przygotowania w jej ramach ogólnej strategii politycznej swej partii do planowanej ofensywy ideologicznej20. Decyzję jej podjęcia wśród nauczycielstwa Biuro Polityczne KC PPR uchwaliło w kwietniu 1947 r. Pod hasłem „upaństwowienia" nauczania większy nacisk położono na zagadnienia polityczne, ekonomiczne i społeczne. Realizacja tych zagadnień miała dać wychowankom „Zdrowe podstawy" pod budowę nowego, materialistycznego światopoglądu ${ }^{21}$.

Po wyborach do Sejmu Ustawodawczego nowego wydźwięku nabrały sprawy naúczania religii i propagowania treści wychowania religijnego w szkole. Środowisko katolickie w Sejmie (posłowie: Jan Frankowski, Aleksander Bocheński i Witold Bieńkowski). stanowiło wobec komunistów opo-

17 Uwagi o niektórych zagadnieniach ustaw konstytucyjnych z 4 i 19 lutego $1947 \mathrm{r}$., „Demokratyczny Przegląd Prawniczy” 1947, nr 3.

18 AAN MOśw., sygn. 414, Zestawienie przepisów o nauce religii rzymskokatolickiej za okres przed uchwaleniem małej Konstytucji z 1947 r.

19 Szerzej: B. Potyrała, op. cit., s. 94 i n.

20 Szerzej: J. Jakubowski, Polityka oświatowa..., s. 138-141; Historia wychowania. Wiek XX, pod red. J. Miąso, T. I, Warszawa 1981, s. 334-338; H. Chylińska, Ideał wychowawczy $w$ okresie rewolucji społecznej w Polsce (1944-1948), Warszawa 1981, s. 60-70.

21 B. Orłowski, O upolitycznieniu, „Głos Nauczycielski” 1947, nr 8. 
zycją nikłą, jednakże przejawijącą znaczną aktywność polityczną. Głos posłów katolickich nie mógł jednak wpłynąć na zmianę sytuacji, o której decydowała lewicowa większość.

Kontrowersje wokół stosunków między władzą ludową a Kościołem, pojawiające się w debatach sejmowych, sygnalizowały narastający, coraz trudniej skrywany, antagonizm między tymi podmiotami życia społecznego i politycznego. Władza starała się stwarzać pozory dążenia do układania poprawnych stosunków z Kościołem. Deklarowała respektowanie uczuć religijnych społeczeństwa. Eksponowała przywiązanie do zewnętrznych przejawów tradycji chrześcijańskich. I tak, na przykład, program Polskiego Radia rozpoczynała pieśń Kiedy ranne wstaja zorze, działacze PPR uczestniczyli w procesjach i innych uroczystościach religijnych, a „bezpartyjny” prezydent Bierut kończył swoją przysięgę słowami: Tak mi dopomóz Bóg! Takich przykładów można by przytoczyć znacznie więcej, jednak „za tą fasadą kryła się zdecydowana ofensywa przeciw Kościołowi” ${ }^{22}$. Również strona kościelna uwikłana była w swoistą grę pozorów. Ze względów zasadniczych nie mogła ustąpić przed ofensywą komunistów, jednak nie była też w stanie wydać im otwartej walki. Taka, nienaturalna sytuacja nie mogła trwać zbyt długo. Z trudem skrywana niechęć, przeradzała się w coraz wyraźniejszą wrogość, z tym, że fizyczna siła państwa była w rękach komunistów.

Rozpoczynający się rok szkolny 1947/48, w dziedzinie nauczania religii i wychowania religijnego prowadzonego w szkołach, zapowiadał się jako trudny. Strona kościelna wiedziała, że stosunek władz szkolnych do religii jest nieprzychylny i nieszczery: atak skierowany jest na nauczanie religii w szkole, na osobę katechety i na samą treść nauki religii. Problematykę tę Komisja Szkolna Episkopatu poddała gruntownej analizie podczas obrad 4 września 1947 r. W czasie tego posiedzenia kierownictwo Komisji Szkolnej objął bp Jan Stepa, gdyż kard. Sapieha złożył ten urząd na jego ręce. Plonem obrad były rezolucje skierowane do Rządu. Dotyczyły one przywrócenia dwóch godzin religii tygodniowo w szkołach zawodowych oraz usunięcia ze szkoły wszystkiego, co podważa i obraża religię i moralność katolicką (chodziło zwłaszcza o wprowadzenie do programów szkolnych uświadonmienia seksualnego). Stosowne rezolucje skierowano też do Episkopatu. Dotyczyły one legalizacji Sodalicji Mariańskiej i Krucjaty Eucharystycznej jako orga-

22 K. Kersten, Narodziny systemu władzy Polski 1943-1948, Paryż 1986, s. 167. 
nizacji szkolnych, braku kwalifikowanych prefektów na ziemiach odzyskanych ${ }^{23}$.

Komisja Szkolna Episkopatu zdawała sobie sprawę z tego, że słabym punktem strony kościelnej $\mathrm{w}$ starciu $\mathrm{z}$ władzami oświatowymi jest poziom przygotowania pedagogicznego katechetów. Dlatego proponowała, aby Episkopat ustalił wymagania egzaminu kwalifikacyjnego dla katechetów, zwłaszcza do szkół średnich. Do programu miałyby wejść takie przedmioty, jak pedagogika, katechetyka i psychologia pedagogiczna. Komisja wyraziła zdanie, że nie należy mianować prefektami księży bez odpowiednich kwalifikacji. Proponowała też organizowanie obowiązkowych kursów dokształcających dla księży katechetów w czasie wakacji.

W drugiej połowie 1947 r. coraz wyraźniejsze stało się odchodzenie władz państwowych od stwarzanych dotąd pozorów „pokojowego współistnienia" z Kościołem. Wygodnym dla władzy pretekstem stała się Odezwa biskupów polskich do wiernych, odczytana w kościołach 28 września 1947 r. Odezwa odnosiła się w części do spraw szkolnych i wychowania młodzieży ${ }^{24}$.

Jednym $z$ narzędzi polityki władz państwowych w sprawie nauczania religii w szkołach było wydawanie rozporządzeń i przepisów wykonawczych w trybie administracyjnym, coraz częściej rezygnując $z$ ich ogłaszania. Jesienią 1947 r. minister oświaty rozesłał do kuratoriów okręgów szkolnych projekt rozporządzenia w sprawie szkolnej nauki religii. Przedstawił w nim przypadki wykraczania prefektów poza nauczanie religii, wykorzystywanie lekcji do innych celów itp. Jednocześnie nakazał władzom szkolnym przeciwstawianie się „przerostom klerykalizmu i bigoterii”, nadużywaniu tradycyjnego uprzywilejowania prefektów. Zalecił przeciwstawiać się „stosowaniu w szkole praktyk religijnych w zakresie przekraczającym nawet tradycje przedwojenne w tym względzie". Polecał ograniczać działanie na terenie szkół organizacji religijnych, przeciwstawiać się utrudnianiu działania organizacjom młodzieżowym - ZMW, OMTUR, a także „chronienie od przerostów klerykalnych istniejących na terenie szkoły organizacji młodzieży, a w szczególności zaś ZHP". Przypominał o dopuszczalności użycia tylko

23 Archiwum Sekretariatu Konferencji Episkopatu Polski (ASKEP), Rezolucje Komisji Szkolnej Episkopatu z dn. 4 września 1947 r. Szerzej o działalności biskupa Jana Piotra Stepy: B. Kumor, Diecezja Tarnowska. Dzieje ustroju i organizacji. 1786-1985, Kraków 1985, s. $292-295$.

24 Asumpt do bardzo ostrej reakcji władz komunistycznych dał passus mówiący, że w Polsce powstały „zakłady wychowawcze na modłę osławionych szkół hitlerowskich”. ASKEP, Odezwa biskupów polskich do wiernych, podpisana przez Prymasa Hlonda (do odczytania z ambon wszystkich świątyń w dn. 28 września 1947 r.), s. 2. 
tych podręczników religii, które miały aprobatę Ministerstwa Oświaty. Kuratorów zobowiązywano do natychmiastowego zawiadamiania ministerstwa „o konkretnych wypadkach jaskrawych przerostów klerykalizmu oraz wszelkich trudnościach, jakie zachodzić moga przy realizowaniu powyższych poleceń" ${ }^{25}$. Działania Kościoła na terenie szkół, które wybiegały poza dotychczasowe, rutynowe zachowania, traktowane były przez władze oświatowe jako nasilenie procesu klerykalizacji szkoły. Hasło przeciwdziałania jej stało się w roku szkolnym 1947/48 najbardziej bodajże nośnym kierunkiem działań na niwie reformowania wychowania szkolnego.

Wzmożenie przez władze państwowe walki z „klerykalizacją” polskiej szkoły było zarazem sposobem odwracania uwagi od własnych działań mających cel wprost przeciwny - stopniowe usuwanie ze szkoły nauczania religii i wychowania katolickiego na rzecz jej pełnego zeświecczenia. Wydaje się, że strona kościelna zdawała sobie $\mathrm{z}$ tego sprawę, jednak przechodziła do coraz głębszej defensywy.

Należy w tym miejscu przypomnieć, że do roku szkolnego 1947/48 włącznie w zasadzie we wszystkich szkołach nauczano religii. Religia, jako obowiązkowy przedmiot nauczania, znajdowała się w programach szkolnych, a w planach godzin nadal była na pierwszym miejscu. Co prawda zakres tego nauczania w wielu przypadkach był ograniczony, jednak zajęcia odbywały się. Działania władz oświatowych nie były wymierzone bezpośrednio w ten przedmiot, a głównie swoiście rozumianą „klerykalizację" szkoły. Znacznie bardziej wyraźne były utrudnienia w zakresie nominacji, przeniesień i zwalniania prefektów. Władze oświatowe pragnęły doprowadzić do sytuacji, w której mogłyby traktować prefektów podobnie jak nauczycieli innych przedmiotów.

Opracowanie nowych wytycznych organizacyjno-strukturalnych dla szkolnictwa na rok szkolny 1948/49 powierzono wiceministrowi oświaty, Władysławowi Bieńkowskiemu (PPR). Ich przygotowanie i wstępna realizacja odbywała się $\mathrm{w}$ atmosferze narastającego napięcia poprzedzającej przesilenie polityczne jesieni 1948 r. Zjednoczenie ruchu młodzieżowego, sierpniowo-wrześniowe plenum KC PPR poświęcone tzw. odchyleniu prawicowo-nacjonalistycznemu, coraz bliższe zjednoczenie polskiego ruchu robotniczego, zapowiadało radykalny zwrot również w polityce oświatowej PPR. Zmierzała ona w kierunku coraz ostrzejszej walki ze wszystkimi przeja-

25 AAN MOśw., sygn. 414, Projekt w sprawie szkolnej nauki religii do Kuratoriów Okręgów Szkolnych. 
wàmi, uznanymi za wrogie przekształceniom socjalistycznym. Niebawem jednak Bieńkowski, autor wytycznych na nowy rok szkolny 1948/49, odwołany został ze stanowiska członka KC PPR za „tendencje prawicowo-nacjonalistyczne" 26 .

W roku szkolnym 1947/48 władze oświatowe nasiliły szykany przeciwko nauczycielom religii. Utrudnienia przybierały różne formy. Wbrew dotychczasowej praktyce, niektóre kuratoria żądały nowych, indywidualnych podań o pracę. Wielu księży prefektów zwolniono bez porozumienia z właściwą kurią. Sprawa misji kanonicznej, jako warunku nauczania religii, uznawana była jednak nadal przez władze oświatowe jako sprawa wewnętrzna Kościoła. Sprawą, która stanowiła przedmiot wielu utarczek między władzami szkolnymi i kościelnymi, był natomiast termin prowadzenia rekolekcji szkolnych. Częstą praktykę prowadzenia ich na początku roku szkolnego starano się zmienić. Władze oświatowe sugerowały, by rekolekcje szkolne prowadzić w okresie Wielkiego Postu.

W atmosferze zaostrzającej się walki politycznej, 30 października 1948 r. odbyła się w Warszawie krajowa narada aktywu oświatowego PPR. Podczas narady krytyce poddano uleganie „fałszywym i reakcyjnym teoriom naukowym i wychowawczym, uginanie się pod presją ideologii drobnomieszczańskiej" 27. Analogiczna narada aktywu oświatowego PPS odbyła się 15 listopada 1948 r. Skrytykowano na niej politykę oświatową PPS, jej „bezkrytyczny stosunek do nauki burżuazyjnej" ${ }^{28}$. Ustalenia obu partyjnych narad oświatowych stały się kanwą obrad konferencji kuratorów okręgów szkolnych, która odbyła się 18-20 listopada 1948 r. Podczas roboczych narad oświatowych, przeprowadzonych we wszystkich okręgach szkolnych, omawiano wytyczne Ministerstwa Oświaty dotyczące wdrażania nowych kierunków wychowania 29 .

Sprawa laicyzacji szkół i zakładów wychowawczych podjęta została również podczas konferencji działaczy oświatowych Stronnictwa Ludowego, która odbyła się w 11- 13 grudnia 1948 r., w Warszawie ${ }^{30}$.

Kongres Zjednoczeniowy polskiego ruchu robotniczego i jego uchwały w istotny sposób zaważyły na określeniu nowej linii polityki oświatowej.

26 W. Góra, Polska Ludowa 1944-1984, Lublin 1986, s. 267.

27 Szerzej: S. Skrzeszewski, Podstawowe zadania oświatowe, Warszawa 1948, s. 11.

28 Aktyw oświatowy PPS przygotowuje się do realizacji nowych zadań, „Robotnik” nr 137, 17 listopada 1948 r.

29 Szerzej: S. Mauersberg, op. cit., s. 234 i n.

30 Por.: S. Mauersberg, op. cit., s. 237-238. 
Jednym $z$ głównych jej celów stała się laicyzacja szkolnictwa. Wyraźne i otwarte stanowisko władz partyjnych mówiące o budowaniu laickiego systemu oświatowo-wychowawczego, zapowiadało w konsekwencji zasadniczą zmianę w podejściu do kwestii nauczania religii w szkole ${ }^{31}$.

Sytuacja w szkolnictwie po Kongresie Zjednoczeniowym była pilnie obserwowana i analizowana przez Komisję Szkolną Episkopatu. Już w styczniu 1949 r. komisja uznała, że jest ona coraz bardziej napięta, zauważyła, że „sfery oficjalne" przyjęły nową taktykę: starają się, aby dzieci szkolne same żądały usunięcia religii $\mathrm{z}$ programu szkolnego. Innym, często stosowanym sposobem, było wywieranie nacisku na rodziców uzależnionych od państwa, by wycofywali swe dzieci z nauki religii. Usunięcie religii ze szkół ułatwiać miało także planowanie lekcji tego przedmiotu jako pierwszej lub ostatniej w danym dniu, by ułatwić uczniom unikanie tych lekcji. Służyć to miało przygotowywanej w roku szkolnym 1949/50 zmianie statusu religii - z przedmiotu obowiązkowego na nadobowiązkowy ${ }^{32}$. Podczas posiedzenia komisji uzgodniono również sposoby bardziej aktywnego przeciwdziałania usuwaniu religii ze szkół ${ }^{33}$. Przejście do ofensywnego przeciwdziałania zamierzeniom laicyzacji szkolnictwa było, według członków komisji, najlepszą bronią przeciw poczynaniom władz oświatowych. Postulowano ponadto by odpowiednim listem pasterskim oświecić i pobudzić rodziców do protestów masowych, mobilizować duchowo społeczeństwo, zachęcając je do „gotowości do cierpienia w służbie Boga", informując o paragrafach prawa, które bronią religii. Konferencja Plenarna Episkopatu w dn. 25-26 stycznia 1949 r. potwierdziła wnioski Komisji Szkolnej ${ }^{34}$.

Sytuacja w szkolnictwie, a zwłaszcza nauczanie religii, była obiektem zainteresowania Biura Politycznego KC PZPR. Na posiedzeniu w lutym 1949 r. pod jęło ono w tej kwestoo ważne decyzje i ustalenia ${ }^{35}$. Kuratorzy okręgów

31 J. Jakubowski, Z problemów polityki oświatowej PZPR w latach 1948-1960, „Z pola walki" 1980, nr 1, s. 44 i n.

32 Protokół posiedzenia Komisji Szkolnej Episkopatu w Krakowie 24 stycznia 1949 r., $\mathrm{w}$ : Wybrane dokumenty z dowodów rzeczowych procesu przeciwko bp. Czestawowi Kaczmarkowi $i$ innym, cz. I, s. 109. Dokumenty te, zszyte i oprawione, znajdowały się w Bibliotece d. Urzędu do Spraw Wyznań, a następnie Departamentu Wyznań Urzędu Rady Ministrów, sygn. bibl. 1532, s. 1-2.

33 Ibidem, s. 3.

34 Protokół Konferencji Plenarnej Episkopatu w Krakowie w dn. 25-26 stycznia 1949 r., w: Wybrane dokumenty..., sygn. 1532, s. 6.

35 A A N KC PZPR, P. 1, T. 4. s. 100-104, Załącznik do protokołu nr 4 z posiedzenia BP KC PZPR z dn. 2 lutego 1949 r. 
szkolnych mieli otrzymać polecenie usunięcia do dnia 1 września 1949 r. księży, zakonników i zakonnic - nauczycieli przedmiotów świeckich oraz wychowawców. Sprawa była dość istotna, pomimo że dotyczyła jedynie 239 osób pracujących w szkołach podstawowych, w tym 35 kierowników (w szkołach podległych Ministerstwu Oświaty pracowało w tym czasie ponad 110.000 nauczycieli). W sprawach dotyczących nauczania religii w szkole zdecydowano wydać okólnik. Dopuszczał on możliwość zwalniania się przez uczniów mających 14 i więcej lat od uczęszczania na lekcje religii, nakazywał przesunięcie nauki religii na pierwsze i ostatnie godziny lekcyjne oraz zapowiadał wprowadzenie regulaminu egzaminów dojrzałości bez religii jako przedmiotu egzaminacyjnego. Ministerstwo zalecało wzmożenie nadzoru administracy jnego i kontroli pedagogicznej nad nauką religii i działalnością katechetów. W programach kształcenia zawodowego nauczycieli postanowiono ograniczyć lekcje religii do 1 godziny tygodniowo.

„Przyspieszenie” antykościelnych działaniach partii i władz państwowych w oświacie na przełomie 1948 i 1949 r. zapowiadało nowy etap tej walki. Wydaje się, że władze kościelne nie spodziewały się tak zdecydowanych działań swych przeciwników. Reakcja Kościoła, bazująca na protestach i odwoływaniu się do przepisów prawa, nie miała większych szans powodzenia. Wszakże władze partyjno-państwowe zamierzały swe działania oprzeć o nowo tworzone przepisy. Ich realizację zapewniać miały instytucje i organizacje podporządkowane tym władzom. Nie bez znaczenia były też pozaprawne środki nacisku zarówno na Kościół, jak i społeczeństwo. W walce tej kwestia szkolnego nauczania religii była bodaj najważniejszą płaszczyzną konfrontacji.

-Działania władz oświatowych zmierzały w kilku kierunkach. Przede wszystkim zwrócono uwagę na nauczycieli religii. Przystąpiono do częstszego wizytowania księży prefektów. W arkuszu spostrzeżeń odnotowywano ocenę lekcji, a zwłaszcza czy stosunek katechety do obecnej rzeczywistośçi jest pozytywny, czy negatywny, jakie jest jego zachowanie podczas przerw, stosunek do organizacji i życia szkolnego. Władze szkolne miały równocześnie sprawiać pozory pełnego przestrzegania wolności religijnych. Unikać należało mechanicznego usuwania krzyży $z$ izb lekcyjnych na rzecz przewieszania ich na boczne ściany „przy okazji” - w czasie remontu, wakacji itp.

Zabiegom władz o wyparcie Kościoła i nauczania religii towarzyszyły działania wspierające te zamiary. Proces laicyzacji szkoły polskiej władze oświatowe rozpoczęły faktycznie już w 1945 r. Pierwsza szkoła „świecka” - bez nauczania religii - powstała 5 lutego 1945 roku w powiecie jarociń- 
skim ${ }^{36}$. Działające w kraju organizacje: Robotnicze Towarzystwo Przyjaciół Dzieci i Chłopskie Towarzystwo Przyjaciół Dzieci miały na celu przygotowanie gruntu pod zupełnie nową koncepcję świeckiego systemu oświatowego ${ }^{37}$. Połączenie RTPD i ChTPD w Towarzystwo Przyjaciół Dzieci (TPD) umożliwić miało eliminowanie wpływów Kościoła $z$ oświaty i wychowania. Zasadniczą dziedziną działania TPD było współdziałanie z państwem w prowadzeniu szkół świeckich, zwłaszcza świeckich liceów pedagogicznych w celu intensywnego szkolenia kadr nauczycielskich. W końcu 1948 roku RTPD i ChTPD posiadały w kraju łącznie 805 placówek. Swym działaniem obejmowały kilkadziesiąt tysięcy dzieci. Ambitne plany rozwojowe na 1949 rok przewidywały ponad trzykrotny wzrost prowadzonych przez TPD świeckich szkół podstawowych i liceów pedagogicznych (odpowiednio z 33 do 100 szkół podstawowych i z 4 do 15 liceów pedagogicznych) ${ }^{38}$.

Wydaje się, że gwałtowność i zakres antykościelnej of'ensywy władz partyjno-państwowych na terenie szkolnym w 1948 r. zaskoczył Episkopat. Masowe rozmiary przyjęła akcja zwalniania księży, sióstr zakonnych i katechetów świeckich. Równocześnie utrudniano lub uniemożliwiano katechetom świeckim zastępowanie księży prefektów, którzy z różnych powodów przestawali uczyć religii w szkołach. W wielu inspektoratach przetrzymywano wnioski o pozwolenia na nauczanie religii. Stało się to przyczyną tego, iż $\mathrm{w}$ niektórych szkołach nastąpiła $\mathrm{z}$ tego powodu nawet kilkumiesięczna przerwa w nauczaniu religii. Wedle ocen kościelnych stan nauczania religii w szkołach powszechnych, w kwietniu 1949 r., przedstawiał się źle: „w 20\% nauki religii $\mathrm{w}$ szkołach nie ma, w $35 \%$ jest nauka religii wyznaczona na papierze w jednej godzinie tygodniowo, a w praktyce jej nie ma, w reszcie $\%$ odbywa się w jednej lub w dwóch godzinach tygodniowo" 39 .

36 J. F. Godlewski, Kościót rzymsko-katolicki wobec sekularyzacji życia publicznego, Warszawa 1978 , s. 148.

37 Robotnicze Towarzystwo Przyjaciół Dzieci powstało w 1919 r. w Warszawie przy CKW PPS. Nazwę tę przybrało w 1926 r. Prowadziło zakłady opiekuńczo-wychowawcze, szkoły i przedszkola, wychowując dzieci w duchu socjalistycznym. W 1946 roku wznowiło działalność. W kwietniu 1949 r., po połączeniu z Chłopskim Towarzystwem Przyjaciół Dzieci, powstało TPD.

38 A AN KC PZPR, P. 1, T. 6, Zestawienie oddziałów, placówek i dzieci objętych akcja wychowawczą RTPD i ChTPD na dzień 1.12.1948 r., s. 218. J. F. Godlewski, Kościót..., s. 155 - przytacza za: K. Jabłońskim („Problemy Wyznań i Laicyzacji”, 1975, nr 44) inne dane: w 1947 r. - 6 szkół TPD (1 943 dzieci), 1948 r. - 31 szkół (10 488 uczniów).

39 Protokół Konferencji Plenarnej Episkopatu odbytej w Gnieźnie dn. 24 i 25 kwietnia 1949 r., w: Wybrane dokumenty..., sygn. 1532, s. 152. 
Decyzje podejmowane przez kierownictwo partyjne wiosną 1949 r. zapowiadały w nowym roku szkolnym 1949/50 nieuchronne zmiany. Nie ukrywano, że przeobrażenia, którym poddana będzie oświata i kierunek wychowania w szkołach znajdują się w centrum uwagi władz. Krytyce poddano zwłaszcza dotychczasowe programy nauczania ${ }^{40}$. W planie godzin dla 11-letniej szkoły ogólnokształcącej pozostawiono 2 godziny lekcyjne nauki religii, a w wykazie przedmiotów szkolnych religia znalazła się na ostatnim miejscu $^{41}$. Sygnalizowało to, że władze oświatowe traktu ją nauczanie religii jako czynnik co najmniej konkurencyjny wobec odgórnie przyjętego, laickiego i materialistycznego systemu wartości wychowawczych, mających obowiązywać w reformowanej szkole.

Posunięcia władz partyjnych i państwowych, w tym zapowiedź zmian programowych, wywołały żywą reakcję Kościoła. W ocenie Komisji Głównej Episkopatu Polski charakter i kierunek działań władz „jest tak dziwnie jednolity, że wskazują na istnienie planu całkowitej laicyzacji życia indywidualnego i społecznego obywateli, ograniczającego ich prawo do wolności sumienia, zakłócającego głęboko wewnętrzne życie kościoła i niweczącego wartości moralno-religijne życia publicznego. (...) Wychowanie materialistyczne jest w swych założeniach wrogie etyce chrześcijańskiej i nauce Kościoła Katolickiego. Praktyka wychowawcza, w duchu materialistycznym, potwierdza tę wrogość i ją potęguje" 42. Stanowisko Kościoła nie wpłynęło oczywiście na zmianę postawy władz.

Wakacje 1949 r. władze wykorzystały na nadanie nowego kierunku szkole polskiej. Nasilenie ofensywy ideologicznej na gruncie oświaty prowadzić miało do gruntownego przeobrażenia ideowo-wychowawczego oblicza szkoły. Latem 1949 r. Sekretariat KC PZPR w swych pracach sporo uwagi poświęcił problemowi stosunków z Kościołem oraz organizacji nowego roku szkolnego. Póstanowił opracować deklarację lojalności, którą katecheci mieli podpisać na początku nowego roku szkolnego ${ }^{43}$.

40 Szerzej: S. Dobosiewicz, O masowq i publiczna krytykę programów, „Nowa Szkoła” 1950, nr 3/4, s. 130-131. Programom zarzucano m.in.: wulgaryzowanie polskiej drogi do socjalizmu, obciążenie elementami nacjonalistycznymi itp.

41 Ibidem, s. 10 i n.

42 AAN Ministerstwo Administracji Publicznej (MAP), sygn. 983, s. 132 i n., Pismo Prymasa Polski Stefana Wyszyńskiego i kard. Adama Sapiehy w imieniu Komisji Głównej Episkopatu Polski z dn. 28 czerwca 1949 r. do Rządu Rzeczypospolitej Polskiej.

43 AAN KC PZPR, P. 2, T. 7, Protokół nr 31 posiedzenia Sekretariatu KC PZPR z dn. 28 lipca 1949 r., s. 11-12 oraz Protokół nr 32 posiedzenia Sekretariatu KC PZPR z dn. 30.07.1949 r. 
Równolegle $z$ poczynaniami władz partyjnych i oświatowych przygotowania do rozpoczęcia nowego roku szkolnego podjęły także władze kościeln e. Komisja Szkolna Episkopatu na posiedzeniu 23 sierpnia 1949 r. dokonała oceny sytuacji w szkolnictwie oraz problemów zarysowujących się w nowym roku szkolnym. Komisja przewidywała narastanie trudności w nauczaniu religii, wzmożenie akcji władz oświatowych mających na celu dążenie do laicyzacji szkoły. W tej sytuacji Komisja uznała, że należy organizować naukę religii w kościołach dla uczniów tych szkół, w których $z$ różnych powodów przedmiotu tego nie wykłada się. Podczas posiedzenia wiele uwagi poświęcono problemowi ideologii wychowawczej systemu socjalistycznego - analizie stanowiska PZPR w kwestii miejsca i roli szkoły w budowie zrębów socjalizmu, kierunków nauczania i wychowania opartego na fundamencie „światopoglądu naukowego". Komisja Szkolna uchwaliła również dyrektywy do rozmów z Rządem w sprawach szkolnych. Sprowadzały się one do postulatów zapewnienia nauczania religii w szkole w wystarczającej ilości godzin, powierzania nauczania religii wyłącznie nauczycielom posiadającym misję kanoniczną, domagania się od władz, aby obsadzanie, zwalnianie i przenoszenie nauczycieli religii odbywało się w porozumieniu $z$ właściwą kurią biskupią, ułatwienia spełniania przez młodzież szkolną praktyk religijnych, a zwłaszcza jej udziału we mszy św. w niedziele i święta oraz na początku i końcu roku szkolnego, spowiedzi i komunii św. trzy razy w roku, a w okresie wielkanocnym w rekolekcjach, nie utrudniania praktyk religijnych młodzieży w internatach i na koloniach ${ }^{44}$. Większość tych postulatów nie miała szans realizacji.

Wyrazem postawy władz PZPR wobec spraw wysuniętych przez Episkopat, było stanowisko zajęte przez Sekretariat KC PZPR 22 września 1949 r. Stwierdzano w nim m.in., że „Rząd nie zamierza zmienić obecnego stanu nauczania religii w szkołach (...) władze szkolne nie będą stawiały przeszkód uczniom w braniu udziału w obrzędach religijnych poza szkołą" 45.

Nowy rok szkolny 1949/50 rozpoczynał się w atmosferze nie sprzyjającej pozytywnemu rozwiązywaniu kościelnych postulatów dotyczących nauczania religii w szkołach, normalizacji statusu duchownych i świeckich na-

44 ASKEP, Protokół z posiedzenia Komisji Szkolnej Episkopatu z dn. 23 sierpnia 1949 r. w Krakowie wraz z Załącznikiem C, Uchwały Komisji Szkolnej Episkopatu jako dyrektywy w sprawach szkolnych dla rozmów z rządem (23 sierpnia 1949 r.).

45 A AN KC PZPR, P. 2, T. 7, Protokół nr 38 posiedzenia Sekretariatu KC PZPR z dn. 22 września 1949 r., wraz z Załącznikiem: „Nasze stanowisko w sprawach wysuniętych przez Episkopat”, s. 226 i n. Także: AAN KC PZPR, P. 2, T. 4, Protokół nr 22 Posiedzenia Biura Politycznego KC PZPR w dn. 21 września 1949 r., s. 570 i n. 
uczycieli tego przedmiotu. Konferencja Plenarna Episkopatu, obradująca 20-21 września 1949 r. na Jasnej Górze, krytycznie oceniła stan spraw szkolnych. Systematyczne ograniczanie katolickiego szkolnictwa prywatnego, narastające utrudnienia $w$ nauczaniu religii oraz postępująca laicyzacja oświaty napawały niepokojem.

$\mathrm{Na}$ początku roku szkolnego pewne zamieszanie w szeregach księży katechetów spowodowała sprawa „przyrzeczenia służbowego”, którego składania wymagały władze szkolne. Komisja Szkolna Episkopatu wyraziła zdanie, „że przyrzeczenia zasadniczo nie zawierają sprzeczności ze światopoglądem katolickim; ponieważ zaś od złożenia przyrzeczeń uzależnione jest w głównej mierze przyjęcie księży do szkolnictwa, księża katecheci, zarówno etatowi, jak i nieetatowi powinni przyrzeczenia składać - o ile władze szkolne będą tego żądały" "46. Stanowisko to podzieliła również Konferencja Plenarna Episkopatu. Owe deklaracje lojalności, obmyślone przez Sekretariat KC PZPR na początku wakacji, choć stały się przyczyną chwilowego zamętu i niepewności, nie dały jednak władzom oświatowym pretekstu do niezatrudniania nauczycieli religii.

We wrześniu 1949 r. zarysował się początek procesu, który w efekcie doprowadził do podpisania w dniu 14 kwietnia 1950 r. Porozumienia między przedstawicielami Rządu Rzeczypospolitej Polskiej i Episkopatu Polski ${ }^{47}$. Droga do porozumienia nie była łatwa. W rozgrywkach z Kościołem „władza ludowa" wykorzystywała wszelkie możliwe sposoby, w tym „rutynowe” naciski na Kościół: m.in. utrudnienia i szykany w oświacie i wychowaniu oraz w normalnym wykonywaniu praktyk religijnych ${ }^{48}$.

Rozmowy Komisji Wspólnej Rządu RP i Episkopatu Polski przebiegały ze sporymi oporami. W skład komisji wchodzili: Władysław Wolski, Edward Ochab i Franciszek Mazur oraz biskupi Zygmunt Choromański, Michał Klepacz i Tadeusz Zakrzewski. Do grudnia 1949 r. odbyło się 12 posiedzeń.

46 Tamże. Również: ASKEP, Protokół z Posiedzenia Komisji Szkolnej Episkopatu z dn. 19 września 1949 r. w Częstochowie.

47 Tekst opublikowała prasa, por. m.in.: Porozumienie między Rzadem RP a Episkopatem, „Słowo Powszechne”, 16 kwietnia 1950 r. Także: Listy pasterskie Episkopatu..., s. $91 \mathrm{i}$.

48 W Dzienniku Urzędowym MAP nr 50, z dn. 5 grudnia 1949 r., poz. 365 ukazał się Okólnik nr 107 z dn. 23 listopada 1949 r. o zgromadzeniach publicznych, który wprowadzał obowiązek uzyskania zezwolenia władz administracyjnych nie tylko na procesje, pielgrzymki itp. odbywające się poza kościołami, ale równiez odbywające się w obrębie kościołów lecz „nie w sposób ustalony tradycją lub przewidziany w akcie uznającym dane wyznanie". 
Wtedy to, po posiedzeniu w dn. 19 grudnia, zarysował się impas w rozmowach. Tymczasem „sprawa dalszych rozmów z klerem" stanęła na porządku kolejnego posiedzenia Sekretariatu KC PZPR w dn. 12 stycznia 1950 r. Sekretariat postanowił rozwinąć akcją polityczno-propagandową przeciwko klerowi za jego nieprzychylne stanowisko wobec Polski Ludowej. W jej wyniku doszło do nasilenia nagonki propagandowej na Kościół. Głównym pretekstem pozostawała sprawa "Caritasu” 49.

23 lutego 1950 r. „stanowisko Episkopatu” omówił na swym posiedzeniu Sekretariat KC PZPR. Min. Wolski zaproponował, aby wydać oświadczenie Komisji Rządowej o stosunku Episkopatu do Rządu Polski Ludowej oraz uchwalić Ustawę, która uzależniałaby usuwanie i obsadzanie księży na probostwach od zgody władz administracyjnych. „W dyskusji członkowie Sekretariatu wypowiedzieli się przeciwko projektowanej Ustawie, uważając ją za przedwczesną (podkr. - H. K.). Sekretariat uchwalił ogłosić oświadczenie Rządu, które powinno szeroko informować społeczeństwo o wrogiej postawie kierowniczych kół Episkopatu do Polski Ludowej i do przemian, jakie zaszły w Polsce z podkreśleniem, że przywileje Episkopatu, przekreślone na skutek przemian społecznych w Polsce, nie mogą być utrzymane. (...) Sekretariat stwierdził, że w związku z tym, że Episkopat zajmuje coraz bardziej agresywna postawę, nie należy się ograniczać do wydania oświadczenia, lecz przejść do konkretnych posunięć" 50. Uchwała Sekretariatu KC PZPR szybko przybrała konkretny kształt. Na posiedzeniu Sejmu w dn. 6 marca 1950 r. premier Józef Cyrankiewicz przedstawił rządowy projekt Ustawy o przejęciu przez państwo dóbr martwej ręki, o poręczeniu proboszczom posiadanych gospodarstw rolnych i o utworzeniu Funduszu Kościelnego ${ }^{51}$.

49 Szerzej: P. Raina, Kardynat Wyszyński. Droga na Stolicę Prymasowska, t. I, Warszawa 1993, s. 180 i n.; A. Micewski, Kardynat Wyszyński. Prymas i maż stanu, t. 1, Paryż 1982, s. 68 i n.; idem: Wspótrzadzić czy nie kłamać? Pax i Znak w Polsce. 1945-1976, Paryż 1978, s. 43 i n.; S. Markiewicz, Państwo i Kościót w Polsce Ludowej, Warszawa 1981, s. 88 i n. 23 stycznia 1950 r., po rewizjach i kontrolach funduszy "Caritasu” na terenie całego kraju, na podstawie zarządzenia ministrów: pracy i opieki społecznej, oświaty oraz administracji publicznej, powołany został zarząd przymusowy tego zrzeszenia.

50 AAN KC PZPR, P. 3, T. 16, Protokół nr 58 posiedzenia Sekretariatu KC PZPR w dn. 23 lutego 1950 r., s. 224 i n.

51 Pozostałości feudalizmu i obszarnictwa będa zlikwidowane. Fundusz Kościelny wyrazem troski Państwa o istotne potrzeby Kościota i duchowieństwa. Przemówienie premiera Cyrankiewicza $w$ Sejmie, "Życie Warszawy”, 7 marca 1950. Sejm RP uchwalił Ustawę o przejęciu przez państwo dóbr martwej ręki, poręczeniu proboszczom posiadania gospodarstw rolnych i utworzeniu Funduszu Kościelnego uchwalił w dn. 20 marca 1950 r. 
Rozmowy Komisji Wspólnej Rządu i Episkopatu dobiegły końca w gęstniejącej atmosferze. Ich uwieńczeniem stać się miało niebawem Porozumienie między Rządem RP a Episkopatem z 14 kwietnia 1950 r. Miało ono sprzyjać tworzeniu atmosfery wewnętrznego spokoju oraz podstaw wzajemnego zrozumienia i współdziałania władz państwowych i kościelnych ${ }^{52}$. W ówczesnych warunkach Porozumienie było efektem dyktatu ze strony partyjno-rządowej. Episkopat w punktach 1-9 Porozumienia podpisywał de facto deklarację lojalności wobec Rządu Polski Ludowej. W zamian Rząd deklarował co najwyżej tolerowanie istniejącego, mocno ograniczającego swobodę Kościoła, status quo. Że deklaracje te nie były szczere, pokazał najbliższy czas. Porozumienie odnosiło się nie tylko do ogólnych problemów związanych ze stosunkami między państwem a Kościołem - rozbudowany punkt 10, dotyczył szczegółów związanych $\mathrm{z}$ nauczaniem religii w szkołach ${ }^{53}$.

Porozumienie, zawarte 14 kwietnia 1950 r. skłaniać dziś może do krytycznych ocen. Było ono jednak ewenementem w „krajach demokracji ludowej”. Stosunki między państwem a Kościołem układały się w Polsce znacznie łagodniej niż państwem a kościołami w Jugosławii, Czechosłowacji, Rumunii, Albanii, Bułgarii i na Węgrzech, nie mówiąc już o ZSRR. Wydaje się, że w Polsce, jak nigdzie indziej w tej części Europy, udało się uniknąć najbardziej drastycznych przejawów walki „władzy ludowej” z Kościołem. I choć wszelki relatywizm w porównywaniu różnych postaci zła wydaje się nie na miejscu, jednak należy podkreślić, iż zawdzięczać to można „specyfice polskiej”. Podstawy prawno-ustrojowe większości krajów demokracji ludowej oraz wynikająca stąd organizacja szkolnictwa, powodowały, że jedynie w Polsce szkolne nauczanie religii, choć stale napotykało opór władz partyjno-państwowych, było realizowane przez siedemnaście powojennych lat.

52 „Pismo Okólne” 1989, nr 17, s. 28-31. Także m.in.: Listy pasterskie Episkopatu..., s. 91-93. Tekst porozumiania publikowała także prasa codzienna.

53 Porozumienie między Rzadem RP a Episkopatem, „Słowo Powszechne”, 16 kwietnia 1950 r. Szerzej m.in.: A. Dudek, G. Pytel, Bolesław Piasecki. Próba biografii politycznej, Londyn 1990, s. 186 i n. Autorzy określają Porozumienie wielkim osobistym sukcesem, ogromnym tryumfem w działalności Bolesława Piaseckiego. 